\title{
Assessment of Sustainable Building by the Participants of the Local Real Estate Market in Częstochowa
}

\author{
Marcin Sitek ${ }^{1}$
}

\begin{abstract}
The inspiration for the research problem discussed in this study was sustainable investments that consist in rational and responsible construction with respect to the environment, combining economic, environmental and social aspects. The aim of the study is to find the answer to the question of whether the local market in Poland notices the benefits of sustainable building. The study proposed the hypothesis that the development of building, especially sustainable building, is a necessary component of leading the economy towards the sustainable building. A questionnaire survey was conducted among the developers to examine the status of sustainable building in local real estate market. The respondents assessed sustainable building, construction costs and limitation of risks. Furthermore, the study also used the data published by the Central Statistical Office of Poland and the Europe 2020 strategy and used the examinations of McKinsey's survey. Analysis of the data derived from the survey revealed that the respondents perceived the sustainable building as a method to reduce costs while emphasizing lower energy consumption and the benefits of the attributes of green buildings. Furthermore, the respondents demonstrated no unequivocal evaluation of risk: answers are not consistent in terms of reduction of the risk involved in sustainable building.
\end{abstract}

Keywords: sustainable building, lead markets, Europe 2020 strategy.

\section{Introduction}

Human activity has always had an impact on the environment and the only changes were observed in the ways and range of the effect. Progress required using the resources, but current needs were often met in an ill-considered, harmful to the environment and even predatory manner. One of the attempts to counteract this unfavourable tendency is the concept of sustainable development, defined by key documents of the United Nations and the European Union. Sustainable development consists in aiming to maintain an equilibrium between human expectations, economic aspects and environmental needs. This is expected to ensure the economic growth in order to meet human needs with respect for and protection of the natural environment. Many years after its formulation (Raport, 1987), the postulate of sustainable development has become an important idea in the European civilization.

Construction represents one of the major industry sectors, aimed at meeting basic material needs of citizens. Determinants that affect the demand on construction services and help develop the construction sector include the level and structure of investment expenditure in the economy, general market tendencies and financial status of people in the population. However, in the case of the problems of sustainable development in 
building, three groups of aspects should be emphasized: environmental, social and economic. Figure 1 illustrates sustainable development based on the 3P model.

Environmental (ecological) aspects are related to the building object in the whole life cycle, likely to lead to changes in the environment, such as stronger greenhouse effect and destruction of the ozone layer, acidification, microclimate, generating waste, water consumption and other aspects that have an effect on global and local environment (OECD, 2010). Counteracting climate change requires implementation of changes in the design, construction, use and demolition of buildings.

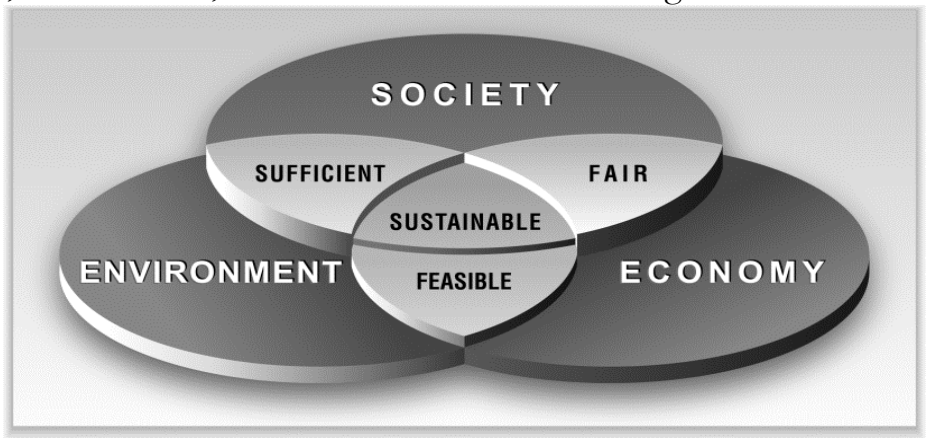

Fig. 1. Sustainable development is based on the 3P (people-plant-profit) model.

Source: author's own elaboration based on (Proczek, 2013)

Social aspects (people) are connected with the building over its life cycle, likely to impact on quality of society life and conditions of indoor microclimate, quality of the internal air and drinking water, acoustic comfort, visual comfort and effective utilization of the surface area.

The economic aspects (profit) are connected with the building in the full life cycle, having an effect on the economic growth of the environment. The economic aspects include cost of building in its life cycle, income generated during its existence (e.g. rent) or stability of the object over its life cycle and energy management (Bloomberg, 2013).

The increasing environmental problem is mainly caused by the overall technological advances, industry, and caused by the increase in the population all over the world. However, the improved standards of living and meeting the needs of people cannot lead to degradation and deterioration of the state of equilibrium in the natural environment. Ideally, sustainable development consists in preparation and implementation, by the authorities, of a strategy of creation of new workplaces and development of the economy, supporting and running business and any type of measures to ensure the common well-being. The European Council in Göteborg and the Sixth Environment Action Programme of the European Community ('Environment 2010: Our future, Our choice' for the years 2001-2010) decided on the necessity of reduction in the effect of the economic growth on environmental degradation. The progress was observed in such areas as air and water pollution. However, the impact on the environment remains unbalanced (Program Innowacje, 2015-2020).

To date, the enterprises located in Poland have substantially reduced emissions of many pollutants and use huge potential of environmental technologies while becoming a leading manufacturer and exporter in certain areas, such as e.g. wind energy, electricity, waste treatment. Enterprises which act according to the principles of sustainable 
development yield not only social and environmental benefits but also increase their revenues by two or even three times (Zegar, 2003).

Conventional construction combines such elements as economy, utility, life and convenience. However, European buildings consume 42\% energy and produce 35\% greenhouse gases in the entire EU. Over $50 \%$ of materials extracted from the earth (after processing) are used in the construction sector (Lead Market 2007), which uses $25 \%$ of natural wood. Furthermore, sustainable building generates nearly $10 \%$ of the European Union's GDP, offering employment to ca. 20 million people in small and medium-sized enterprises (Bunikowska, 2010). Compared to conventional building, the concept of sustainable building also contains the ecological aspect. Therefore, sustainable building has become one of the priority sectors of the European Union.

Strategy of sustainable development in the construction sector also concerns the reduction in the demand for energy and consumption of raw materials, increasing product life and period of building use, disposal of building materials and components, and minimization of any damage to the natural environment. As a response to key challenges of sustainable building, the European strategy was specified for this sector, oriented especially on energy efficiency and ${ }^{1}$ using green energy.

The aim of the study is to present the assessment of sustainable building by the participants of the local real estate market in Poland. The study proposed the hypothesis that the development of building, especially sustainable building, is a necessary component of leading the economy towards the sustainable development.

\section{Research Methodology}

The data used to achieve the study aim and support the adopted thesis were derived from the results of the survey conducted among the entities operating in the real estate market. The questionnaire concerning the local real estate market was dedicated to developers and entities operating in the real estate market in 16 enterprises that operated in the local market of Częstochowa, Poland. The study sample size was 50 people. The respondents assessed innovative activities of the enterprises they work for and evaluated the risk involved in implementation of innovations in these enterprises. They also carefully assessed sustainable building, construction costs, efficiency, health in workplaces and risk limitation. Furthermore, they evaluated real benefits resulting from this type of building in the local market.

The study also used the results of the study concerning the situation of the sustainable building in Poland started in 2013 by Buro Happold within the initiative Construction Marketing Group (Analiza rynku.., 2015). The questions the respondents were asked concerned perception of sustainable building by the respondents. Furthermore, the questions concerning the costs of construction in sustainable building were oriented to developers whereas those concerning risk limitation - to investors. The analysis is the first study concerning the topic of sustainable building in Poland. The questionnaire was

1 The social aspect of the sustainable development is also contained in the UN's strategy. On 6 January 2012 in Abu Dhabi, the Secretary-General of the United Nations Ban Ki-moon started the International Year of Sustainable Energy for All. 
prepared in cooperation with the consulting firm $\mathrm{PwC}^{2}$. Data analysis was prepared by Buro Happold in cooperation with Colliers International. The study concerned only the buildings used for commercial purposes or offices. The number of study participants was 115 respondents: developers, investors and main tenants.

The conclusions concerning the statement that the development of building, especially sustainable building, represents a prerequisite for leading the economy towards sustainable development, were developed based also on the survey by McKinseya \& Corporation (2015) conducted in the form of the questionnaire oriented at business leaders of the biggest enterprises in Poland, data from the Central Statistical Office of Poland (GUS, 2007-2013) and the National Cohesion Strategy (2007-2013, 2-14-2020).

The methodology adopted in the study allowed for presentation of the evaluation of sustainable building by the participants of the local real estate market in Częstochowa compared to the whole Poland and for supporting the proposed thesis that sustainable building is conducive to consciously formed relations between the economic growth, care for the environment and quality of life.

\section{Lead Market Initiative (LMI). Role of sustainable building.}

In 2007, the European Commission (EC) promoted the development of innovation-based European economy as a measure to reinforce its competitiveness in the global market. For this purpose, the EC started the lead market initiative (LMI) to implement the innovation-based strategy (KOM, 2007).

The initial date of the initiative was 21 December 2007. Commission of the European Communities: Commission to the Council, European Parliament, European Economic and Social Committee and the Committee of the Regions inaugurates the work on the tools that would allow for increasing the contribution of innovative products and technologies in the most potential sectors of the economy (lead markets). These activities were collected into a single package called Lead Market Initiative for Europe.

Six markets were enumerated in the initial phase of the initiative. These are protective textile products, construction consistent with the principles of sustainable building, recycling, products of biological origin and renewable energies. These markets can perform the role of innovation leaders due to their specific nature, which makes them one of the most suitable instruments to stimulate innovations. As can be seen, one of these markets is sustainable building as a market with innovative potential, conducive to competitiveness and creation of new workplaces in the European economy since the idea of sustainable development as a balance between economic, environmental and social aspects relates directly to the construction sector (obviously, in a manner that allows for development of present generations and the generation to come).

Innovations are the solutions aimed at sustainable development, which change manufacturing methods through the development of technologies, products and services that limit the impact on the environment. They are particularly important in the construction market, where the concept of sustainable development is gaining in

2 PwC Polska (Privatewaterhouse Coopers Sp. z o.o.) offers services of auditing and tax, legal and business counselling. 
importance and the number of low-energy passive buildings is gradually increasing. The construction sector is being developed so that the buildings should ideally generate energy by itself or even sell the energy to the outside network.

Buildings and products used for construction have an impact on the environment. According to the data presented by the European Commission, the construction sector consumes around $42 \%$ of the energy ${ }^{3}$ and emits $35 \%$ of greenhouse gases in the entire European Union. This sector in Europe is responsible for ca. $50 \%$ of the use of natural resource, $30 \%$ of water consumption and $33 \%$ of all waste produced ${ }^{4}$. The concrete industry consumes 20 billion tons of aggregate materials, 1.5 billion tons of cement and 800 million tons of water (according to the Environmental Programme of the United Nations this accounts for 20\%) (Construction ... 2015).

The European Commission assumes that in the building sector, there are profitable opportunities for substantial reductions in consumption of energy and carbon dioxide emissions and increasing the contribution of renewable energy sources which can lead to the achievement, by 2020, of the goal of $3 \times 20 \%$ (Kim et al, 2017; Zuo et al, 2016).

This means the necessity of $20 \%$ reduction of carbon dioxide emissions by 2020 compared to the emissions from 1990, improved energy efficiency in the same period by $20 \%$ and increasing the contribution of energy from renewable energy sources in total energy generation to $20 \%$. According to the estimates of the European Commission, non-achievement of these goals will lead to financial losses in the domestic gross product in the European Union from 5 to $20 \%$.

A comprehensive document which has a substantial effect on the construction industry is the EU Sustainable Development Strategy (Rada.., 2006) renewed in 2006, aimed at protecting against climate changes and utilization of clean energy, sustainable consumption and production and protecting natural resources. A similar document used in Poland was Poland Sustainable Development Strategy. The specific goals and objectives in individual sectors of the economy were specified in the document called the National Sustainable Development Strategy by 2025 (Ministerstwo.., 2013).

\section{Sustainable building according to the participants of the real estate market}

The sustainable development is connected with any innovativeness, with particular focus on innovations concerning changes in the method of organization and management of the enterprise or country's economy, technological innovations and innovations with ecological nature (Zuo et al. 2016). These changes translate into the increased profits and incomes of the enterprises. The enterprises that reduce consumption of materials and components in their business activity are perceived as "environmentally friendly", which allows for generating additional revenues and opportunity for new initiatives. These changes improve the well-being of society and lead to the economic growth, greater social cohesion and improved quality of the environment through minimization of the harmful effect of production and consumption on the condition of the environment. The Europe 2020 Strategy was

\footnotetext{
3 http://www.unep.or.jp/ietc/focus/EnergyCities1.asp

${ }^{4}$ Statistics of the European Commission
} 
implemented in 2010 by the European Council (strategy for the sustainable economic growth). The outcomes expected from the Europe 2020 Strategy include low-emission economy which effectively manages the resources, creates new "green" workplaces and ensures social cohesion based on environmentally-friendly technologies and knowledge.

The examinations conducted in 2016 among the participants of local real estate market, compared to the results of the survey of the situation of sustainable building in Poland obtained by Buro Happold (Construction..2015), concerning only the buildings for commercial use and offices, allowed for answering by the respondents whether the local market perceives benefits of sustainable building and whether developers and investors perceive sustainable building as profitable. Furthermore, the thesis proposed in the study that the development of the construction sector, especially sustainable building, is the prerequisite for leading the economy towards sustainable development, is supported by the conclusions drawn from the survey by McKinsey (2015) among leaders of the biggest companies in Poland, data by the Central Statistical Office (GUS, 2007-2013) concerning the examinations of innovations in microenterprises and the data obtained from the Responsible Business Forum (2014) (questionnaire).

In the questionnaire survey conducted in 2016 in the local market, the respondents were asked about innovative activities in their enterprises, evaluation of risk during implementation of innovations from the standpoint of the local market, evaluation of sustainable building in this market, what the benefits of implementation of sustainable building in the local market are, and whether developers perceive sustainable building as profitable.

In the group of questions concerning innovations, the respondents were asked in particular about motivations and types of innovations, support for innovative activity, types of barriers, risk, its identification and evaluation of future activities.

Furthermore, the second group of questions concerned the risk, its measurement, evaluation of its activity and prospects for the future. The findings demonstrated that $68 \%$ of the respondents declared implementation of innovations in their business activity, with the enterprises focusing on technical and technological innovations followed by marketing innovations $(36 \%)$. The motivations indicated by the respondents include pressure of the competitors (44\%), increased share in the market $(32 \%)$, whereas reduction in the harmful effect on the environment was found only in $18 \%$ of the answers. Respondents emphasized the reduction in risk related to innovations due to collaboration with other entities. Furthermore, while assessing the risk of innovative activities as medium-level, the respondents emphasized that this risk (28\%) is a very important factor that limits this activity. The barriers for implementation of innovations perceived by entrepreneurs in the local market include strong competition, lack of financial and human resources and poor distribution channels. When assessing the future activities of the enterprise, $56 \%$ of the respondents claimed that they maintained a medium level of innovations in order to minimize the risk of bankruptcy.

The last group of questions about sustainable building in the local market in Częstochowa concerned the benefits of implementation of sustainable building in the market and perception of its profitability. The respondents, asked about the benefits concerning sustainable/green buildings, answered that the operating costs, i.e. energy and water, are lower than in the conventional building (54\%) (Sheldon and Zik, 2013) 
and that sustainable building shows tendencies for reducing the maintenance costs in long-term use (40\%). Furthermore, $53 \%$ of the participants of the local market, most likely due to its size and level of development in this market, did not have any opinion about cost reduction. Some $43 \%$ of the respondents pointed to a noticeable benefit: the lack of impact on the natural environment (pollution), with only $20 \%$ claiming that the certified buildings have higher rate of return on investments (Jalaie and Irade, 2015). This statement suggests that certification, according to the respondents, does not guarantee the achievement of benefits of sustainable buildings. Nevertheless, $50 \%$ of developers in the local market claim that higher costs of design and construction of sustainable buildings will be repaid in the phase of use and will be gradually reducing. This suggests that for part of developers, the certificate remains the most important parameter of the measurement of sustainable investment.

The results of the examinations of the situation of sustainable building in the Polish market demonstrated:

- $99 \%$ of respondents pointing to the benefits of reduced operating costs, i.e. energy and water consumption and emissions of carbon compounds,

- indication by $90 \%$ of respondents of reduced maintenance costs at long-term use and limitation of the negative impact on the natural environment while emphasizing segregation/recycling in sustainable buildings,

- substantial reduction of the investment risk as a benefit of sustainable building - the respondents $(57 \%)$ claimed that the certified buildings have higher rate of return on the investment,

- in the general survey in Poland, the respondents $(76 \%)$ claimed that the surplus costs of design and construction of sustainable buildings will be decreasing.

Analysis of the results of the examinations of the local market in the context of the national market clearly points to substantial differences. The causes include insignificant number of sustainable investments for commercial use and offices in the local market, low awareness of the benefits of obtaining the certificate and relatively low number of current certified buildings in the analysed market. Furthermore, noticeable differences in the answers concerning higher costs (national market: by 2-10\%, local market: by 15 to even $25 \%$ ) of construction of sustainable buildings are connected with using modern technologies (their strong effect: $87 \%$ ) and the use of green materials (strong effect: $66 \%)$

The survey conducted by McKinsey \& Company in the form of the questionnaire among the business leaders and developers and conclusions from the questionnaire survey in the local market confirm the thesis that the development of the construction sector, especially sustainable building, is the prerequisite for leading the economy towards sustainable development, since the above surveys showed that innovations are considered as a driver of the economic progress and key determinant of progress of societies (Boeve-de Pauw et al. 2015). This thesis was also confirmed by the reports from the Centre for Research and Statistical Education of the Central Statistical Office of Poland (GUS 2007-2013), which examined microenterprises concerning the indices of innovative activities (share of revenues on sales and implementation of innovative products in revenues of microenterprises in total was $4.2 \%$, whereas in the local market, 
this value was $1.1 \%$, cooperation with other entities in terms of innovative activity was $5.9 \%$ in total and $3.2 \%$ in the local market).

The assumed thesis concerns the development of the construction sector, especially the sustainable building, where innovations are a key determinant of society development. It is cities where centres of innovation and development are located and human and social capital is accumulated. There are also centres of ideas, commerce, culture, science, productivity and social growth. With their benefits, cities have led to social and economic advances. The Sustainable Cities programme was established as a response to Global Compact Poland to the UN's Sustainable Development Goals, which have become a new roadmap for the world. The statistics concerning cities show that:

- half of world population $(50 \%)$, i.e. $3.5 \%$ billion people live in cities,

- 60\% of people all over the world will be living in cities by 2030 (80\% in Europe),

- cities take only 3\% of the Earth surface,

- 65\% of world GDP will be generated by 600 biggest cities in the world (by 2025),

- 1 billion new consumers will be present in cities by 2025,

- ca. $75 \%$ of world energy is consumed by cities,

- ca. $75 \%$ of world carbon dioxide emissions are observed in cities,

- 60\% of population lives in 914 cities in Poland,

- 800,000 tons of garbage is generated every year in Warsaw.

Therefore more and more attention should be paid to sustainable development of cities due to the urbanization processes and the cities should be responsible for using the resources, water management, energy efficiency, effective management of the public space and municipal management.

General characterization of the city of Częstochowa as a city with district status that implements the sustainable development strategy ${ }^{5}$ results directly from the report "Sustainable development of cities" prepared by "Polityka Insight" at the request of the Polska Fundacja im. Roberta Schumana and Fundacji Konrada Adenauera in Poland within the Europolis project. The report examined 66 cities with district status that implement the strategy of sustainable development and the ranking of Polish cities was created in 2016 (Kwiatkowska and Piłat. 2016). "Polityka Insight" evaluated cities from the environmental, political, economic and social standpoints using 71 indices such as e.g. energy sector in the local market, air protection, waste management, employment, transport, demographic changes, conditions of living, and education. After standardization of the measures, they were calculated as a mean for 2012-2014 in order to balance the changes in economic tendencies. The report was prepared based on averaging the results of four groups of evaluation of development. The maximal score was 100 .

5 Since 2003, Częstochowa has developed and implemented the local energy policy, showing the activity in all the areas of interest, i.e. energy planning, free market of electricity and improved energy efficiency. The strategic objective of the city of Częstochowa is constant presence in the group of cities in the EU engaged in sustainable energy management and protecting the Earth climate. (Kwiatkowska.Pilat. 2016). Częstochowa is now at 33rd position among 44 cities with similar size in Poland. 
In general classification, Częstochowa is at 45th position (in 66 cities with district status) with 400.1 points (mean: 428 points). The general ranking was affected by low assessment in social terms - Częstochowa was at 51st position, with 489.3 points (mean: 529 points). With regards to the evaluation of the political aspect, Częstochowa took 45th place and obtained 372.1 points (mean: 401.6 points). Economic indices of Częstochowa led the city to the 42th place with 242.6 points. In terms of the environmental development, the city scored the highest number of points, reaching the 30th place (496.4 points), substantially higher than the mean (supply of green energy, also to sustainable building from 2004 to 2010: savings of 108GWh, reduced emissions of $\mathrm{CO}_{2}$ by 46,000 tons, reduction in water consumption of 430,000 $\mathrm{m}^{3}$ ).

Position of the city of Częstochowa in the above ranking provides the characterization of the local market and shows how the city used opportunities of 25 years of transformation, whether it succeeded in building the innovative economy aimed at sustainable development. Furthermore, in the mini-ranking focused on transport, human capital, willingness to cooperate and easiness of running business (Cho and Lee, 2015), that is, the areas free of innovative activity, Częstochowa was on the 33rd place (middle position of the list) (Peng et al. 2015). The highest (10th) position in this ranking was taken by the city in the easiness of running business, followed by the 21st position in the category of human capital and 31st position in the category of cooperation. The city was almost at the end of the table in the category of production infrastructure.

Analysis of the place of Częstochowa in the ranking of the cities with district status in Poland clearly points to poorly developed local market (Lepri et al. 2015; A New Urban., 2015), little popular innovativeness and, consequently, difficulties in introducing the city into the sustainable development despite the easiness (10th position) of running business and obviously large opportunities of using business to promote sustainable city.

Therefore, the cities included in local urban complexes face the challenge concerning sustainable development, with particular focus on sustainable building .

\section{Conclusions}

The aim of the study was to find the answer to the question of whether the local market in Poland perceives the benefits of sustainable building. The study presented the concept and strategy of sustainable development, with particular emphasis on sustainable building. The assessment of sustainable building in the opinion of participants of the real estate market was based on the results of the questionnaire survey in the local market and national market.

The analysis presented in the study demonstrated for both local and national markets that:

- the construction market shows sustainable building as a prospective investment,

- through energy efficiency and reduced water consumption, sustainable buildings help decrease operating costs at long-term use, which, as savings, allow for the return of the excess construction costs,

- to most of the participants of the real estate market, the certificate remains the most important parameter of the measurement of sustainable investment, 
- statistics on ecology and environmental protection concerning sustainable cities demonstrated that more and more attention should be paid to sustainable development of cities since the cities have to be responsible for utilization of resources, water and energy management, effective management of public space and municipal management, - the surplus costs of design and construction of sustainable buildings will be decreasing. The findings confirmed the proposed thesis that the development of building, especially sustainable building, is a necessary component of leading the economy towards the sustainable building.

Analysis of the questionnaire survey, both limited to the local market and those concerning the national market, clearly suggest creation of the holistic systematic solutions that support innovative activities since sustainable building is one of the markets with innovative potential, conducive to competitiveness and creation of new workplaces in the European economy since the idea of sustainable development as a balance between economic, environmental and social aspects relates directly to the construction sector (obviously, in a manner that allows for development of present generations and the generation to come).

\section{References}

Analiza rynku zrównoważonego budownictwa w Polsce. Badania percepcji rynku. (2015). Construction Marketing Group

A New Urban Agenda. (2015): Introduction on the Special on "Sustainable Urban Development". Sustainability, Vol. 7, Issue 8, pp. 10000-10006

Bloomberg New Energy Finanse. (2013). Global Total New Investment in Clean Energy. Retrieved from: http://about bnef.com/presentations/global-trends-in-clean-energy -investment. Access on: 10.10.2016.

Boeve-de Pauw, J., Gericke, N., Olsson, D., et al. (2015). The effectiveness of education for sustainable development. Sustainability, Vol. 7, Issue 11, pp. 15693-15717.

Bunikowska, J. (2010). Przyszłość europejskiego sektora budowlanego. Zrównoważone budownictwo, "Biuletyn Euro Info"

Cho, Ch., Lee, S. (2015). How Firm Can Get Ideas from Users for Sustainable Business Innovation. Sustainability, Vol. 7, Issue 12, pp. 16039-16059.

Construction Marketing Group, World Green Building Council (2015). Analiza rynku http://ocdn.eu/ zrównoważonego budownictwa. Badanie percepcji rynku. Retrieved from:

/jcmsforbes/cad6c87bd04c39a2be04b16585e2232f.pdf. Access on: 10.10.2016.

Responsible Business Forum. (2014). Biznes na rzecz zrównoważonych miast. Analiza Tematycz̧na, Nr $2 / 2014$.

GUS. (2007-2013). Centrum badań i Edukacji Statystycznej GUS, Raport Końcowy. Badanie innowacji w mikroprzedsiębiorstwach. Retrieved from: http://stat.gov.pl/files/ $\mathrm{gfx} /$ portalinformacyjny/pl/defaultstronaopisowa/5804/1/1/raport_badanie_innowacji _w_ mikroprzedsiebiorstwach.pdf. Access on: 05.02.2017.

Jalaei, F., Irade, A. (2015). Integrating building information modeling (BIM) and LEED system at the conceptual design stage of sustainable building. Sustainable Cities and Society, Vol. 18, pp. 95-107.

Kim,K., Park, H., Kim, H. (2017). Real options analysis for renewable energy investment decisions in developing countries. Renewable \& Sustainable Energy Rviews, Vol. 75, pp. 918-926.

KOM (2007). 860. Komunikat Komisji do Rady, Parlamentu Europejskiego, Europejskiego Komitetu Ekonomiczno-Społecznego oraz Komitetu Regionów. Inicjatywa rynków pionierskich dla Europy. Komisja Europejska. Bruksela2007. Retrieved from: http://eurlex.europa.eu/legal-content/PL/TXT/PDF/. Access on: 29.08.2013. 
Kwiatkowska,E., Pilat.E. (2016). Ranking polskich miast.Częstochowa (nie)zrównoważona? Retrieved

http://czestochowa.wyborcza.pl/czestochowa/1,150461,20212658,raportmiastach-czestochowa-nie-zrownowazona.html. Access on: 10.09.2016.

Lead Market Initiative for Europe, (2007). [załacznik 1 - KOM(2007) 860 wersja ostateczna]; o-polskich-

Lead Maket Initaive for Europe-Acion plan for sustinable contrucion" SEC(2007) 1729] \{COM(2007) 860 final; SEC(2007) 1730\}. Retrieved from: http://www.zb.itb.pl/files/zb/dokumenty/lmi.pdf. Access on: 29.08.2013.

Lepri, B., Antonelli,F., Pianesi, F., et al. (2015). Making big data work: smart, sustainable and safe cities. Ocean \& Coastal Management, Vol. 118, part B, pp. 282-289.

McKinsey \& Company. (2015). Raport: Polska 2025. Nowy motor wzrostu w Europie. Retrieved from: http://mckinsey.pl/publikacje/raport-polska-2025-nowy-motor-wzrostu- w-europie-2/. Access on: 02.02.2016.

Ministerstwo Administracji i Cyfryzacji (2013). Polska 2030. Trzecia fala nowoczesności. Dlugookresowa Strategia Rozwoju Kraju.Warszawa. Retrieved from: https://mc.gov.pl/ files/wp-content/uploads/2013/02/Strategia-DSRK-PL2030-RM.pdf. Access on: 20.08.2013.

National Cohsion Strategy. (2007-2013, 2014-2020). Retrieved from:https://www.google.pl/? gws_rd $=$ ssl\#q $=$ narodowa + strategia + sp $\% \mathrm{C} 3 \% \mathrm{~B} 3 \mathrm{jno} \% \mathrm{C} 5 \% 9 \mathrm{Bci} \& * \& \mathrm{spf}=673$. Access on: $\quad$ 02.02.2016.

OECD (2010). Green Growth Strategy. Retrieved from: http://www.oecd.org/greengrowth/. Access on: $\quad$ 10.10.2016.

Peng, Y., Lai, Y., Li, X.,et al.(2015). An alternative model for measuring the sustainability of urban regeneration: the way forward. Journal of Cleaner Production, Vol. 109, pp. 76-83.

Proczek, R. (2013). Pojęcie zrównoważonego rozwoju, Retrieved from: http://urbnews.pl/pojeciezrownowazonego-rozwoju/. Access on: 10.10.2016.

Program Innowacje. (2015-2020). Biznes - Nauka w ramach Inicjatywy Sekretarza Generalnego ～ONZ Global Compact (Global Compact) w Polsce. Retrieved from: http://www.pte.pl/ pliki/2/12/Innowacje.pdf. Access on: 05.01.2016 r.

Rada Unii Europejskiej (2006). Przegląd Strategii UE Dotyczącej Trwałego Rozwoju (EU

Odnowiona Strategia, Bruksela. Retrieved from: http://arc.wfosigw.olsztyn.pl/ pliki/renewed_eu_sds_pl.pdf. Access on: 29.08.2013.

Raport, (1987). Nasza Wspólna Przyszłość. Światowa Komisja G. Brundtland do Spraw Środowiska i Rozwoju Organizacji Narodów Zjednoczonych. Retrieved from:

http://pl.bssb.be/wladza/wladze/brundtland-nasza-wspolna-przyszlosc/. Access on: 10.10.2016.

Sheldon, S., Zik, O. (2013). Water scarcity: an energy problem. Internal Mechanical Engineering Congress and Exposition - 2012. Vol. 6, part A, B, pp. 1623-1632.

Zegar, J.S. (2003). Kierowanie zrównoważonym rozwojem społeczno-gospodarczym (ekorozwojem). Monografie i Opracowania 522. Wydaw. SGH w Warszawie - Oficyna Wydawnicza, Warszawa.

Zuo, J., Xia, B., Chen,Q., et al. (2016). Green building rating for office building - lessons learned. Journal of Green Building, Vol. 11, Issue 2, pp. 131-146. 